\title{
When are Women as Corrupt as Men? Gender, Corruption and Accountability in the UK parliamentary expenses scandal
}

DOI:

10.1093/sp/jxz045

\section{Document Version}

Accepted author manuscript

Link to publication record in Manchester Research Explorer

Citation for published version (APA):

Waylen, G., \& Southern, R. (2019). When are Women as Corrupt as Men? Gender, Corruption and Accountability in the UK parliamentary expenses scandal. Social Politics, 0, [jxz045]. https://doi.org/10.1093/sp/jxz045

\section{Published in:}

Social Politics

\section{Citing this paper}

Please note that where the full-text provided on Manchester Research Explorer is the Author Accepted Manuscript or Proof version this may differ from the final Published version. If citing, it is advised that you check and use the publisher's definitive version.

\section{General rights}

Copyright and moral rights for the publications made accessible in the Research Explorer are retained by the authors and/or other copyright owners and it is a condition of accessing publications that users recognise and abide by the legal requirements associated with these rights.

\section{Takedown policy}

If you believe that this document breaches copyright please refer to the University of Manchester's Takedown Procedures [http://man.ac.uk/04Y6Bo] or contact uml.scholarlycommunications@manchester.ac.uk providing relevant details, so we can investigate your claim.

\section{OPEN ACCESS}


When are Women as Corrupt as Men? Gender, Corruption and Accountability

\section{Georgina Waylen and Rosalynd Southern}

Corresponding Author:

Georgina Waylen,

Deparment of Politics,

University of Manchester,

Manchester M13 9PL.

Email: georgina.waylen@manchester.ac.uk

Phone: 01612754770

Rosalynd Southern,

Department of Communication and Media,

University of Liverpool,

Liverpool L69 3BX. 


\section{Email r.southern@liverpool.ac.uk}

\section{Phone 01517950500}

\section{Biographical Notes}

Georgina Waylen is Professor of Politics at the University of Manchester. From 2012-2017 she was PI on a European Research Council Advanced Grant 'Understanding Institutional Change: A Gender Perspective' ((UIC-295576). She is a co-director of the Feminism and Institutionalism International Network (FIIN). She has published widely on gender and politics in journals such as World Politics, Comparative Political Studies, Public Administration, Politics \& Gender, and the European Journal of Politics and Gender. Her book Engendering Transitions: Women's Mobilization, Institutions and Gender Outcomes was awarded the Victoria Schuck Prize for the best book published on women in politics in 2007.

Rosalynd Southern is a lecturer in Political Communication at the University of Liverpool Her research primarily focuses on online political communication during election campaigns. She has analysed online campaigning at the last three UK general elections and during the EU referendum. In addition to this, she has conducted work on female politicians and their use of, and treatment via, various media. She has published in Parliamentary Affairs, Electoral Studies and the Journal of Elections, Public Opinion and Parties. Email: r.southern@liverpool.ac.uk. 


\section{Acknowledgements and funding statement}

This research was funded by European Research Ccouncil Advanced Grant 'Understanding Institutional Change: A Gender Perspective' (UIC-295576). The authors would like to thank everyone we interviewed and all those who commented on earlier versions of this paper, including at APSA, Harvard University (particularly at the Gender Workshop organized by Jennifer Piscopo), EUI, University of Gothenburg, NYU, University of Manchester and at various UIC events, including Rosie Campbell, Sarah Childs, Emma Crewe, Shirin Rai and Laurel Weldon. Georgina Waylen would also like to thank Rosalind Shorrocks for her advice on some of the quantitative aspects of the paper and Louise Wylie for her help with the final stages of the data analysis.

\section{Abstract}

Are women less corrupt than men? Although research reinforced this popular assumption, proposing more women in government to reduce corruption, recently scholars have challenged it. Analysing the 2009 UK parliamentary expenses scandal using a gendered institutionalist approach, we show women office-holders' propensity for corruption is context dependent. Male and female office-holders engage in similarly corrupt behavior when accountability is low. But subsequently when accountability is high they respond to and are treated differently for perceived 'wrong-doing'. Comparing low and high accountability contexts using in-depth case-study research, shows how the relationship between corruption, accountability and risk aversion is gendered. 


\section{Introduction}

It has long been assumed that women are less corrupt than men, a belief that has been reinforced by influential scholarly research (see Dollar, Fisman and Gatti 2001; Swamy 2001). However, the popular contention that women are always less corrupt than men and therefore increasing the numbers of women in government and public office can alleviate the problem of corruption has also been challenged (Sung 2003, Goetz 2007). Scholars are now exploring the precise conditions under which women and men exhibit similar or different corrupt behavior. There is increasing evidence that women office-holders are more likely to behave corruptly in some contexts, and in particular, in those of low accountability (Esaray and Schwindt-Bayer 2018). We further these debates by analysing gender differences in one important recent incidence of corruption: the 2009 UK parliamentary expenses scandal.

This paper fills gaps in our knowledge of gender and corruption, and particularly of accountability and risk aversion, in several ways. It contributes new findings, not only about when male and female office-holders will act corruptly in contexts of high or low accountability, but also about their responses to accusations of corruption, based on actual behavior rather than perceptions, as has hitherto been the case. To this is added an examination of whether women office-holders are treated differently to male office-holders. 
Through the first systematically gendered analysis of one notorious parliamentary corruption scandal in a long-standing democracy, we demonstrate the utility of single case study research using mixed methods for generating new insights, providing an important addition to the large-n, survey based and experimental research data that currently dominate the field. We use a gendered institutionalist framework to argue that the pre-2009 'gentleman's club' UK parliamentary expenses regime is better understood as an informal institution with a preponderance of informal rules and norms, and low levels of accountability - even if the wider UK political context was one of high accountability.1 As such, our approach is in sympathy with work on corruption in disciplines such as anthropology that sees 'everyday' corruption as a complex social activity regulated by complex rules and norms requiring in-depth investigation (Blundo and Olivier de Sardan 2006). Adopting this approach to analyse a single case increases our understanding of gender, accountability and corruption, as our choice of case - the UK expenses scandal - allows us to directly compare for the first time the behavior of male and female office-holders in an informal regime of low accountability immediately prior to the corruption scandal, with their behavior both during the scandal and subsequently under a new more formal high accountability regime. It gives new insights into the micro-foundations of the links between corruption, gender and accountability that large n studies cannot.

Our case, the UK parliamentary corruption scandal, came to prominence in May 2009 when The Telegraph newspaper published leaked documents detailing the abuse of MPs' expenses, including claims for luxurious and unnecessary items and the outright manipulation of the rules on MPs' 
accommodation. The huge public outcry led to resignations, an official investigation in which more than half of MPs were asked to repay expenses, and increased disillusionment with the political class. The old discredited informal expenses regime was hurriedly replaced by a new more formal, accountable and transparent regime run by the newly created Independent Parliamentary Standards Authority (IPSA). To discern whether there were significant gender differences, the paper asks how three elements - the lax, informal and unaccountable 'gentleman's club' regime that operated in the run-up to the 2009 expenses scandal, the expenses scandal itself and its aftermath - were gendered. In particular it considers whether male and female MPs behaved differently before, during and after the scandal; and finally it asks whether those seen to be corrupt were treated differently because of their gender.

To answer these questions, the paper uses quantitative data sets compiled by us (and others) from the databases of The Telegraph, the Independent Parliamentary Standards Authority (IPSA) and Parliament, as well as qualitative data from interviews, memoirs, media reports and official documents. Data were difficult to collect, classify and analyse, making the use of multiple sources so important. Given the controversial subject matter, interviewees were often unwilling to be forthright even on condition of anonymity. The informal and non-transparent nature of pre-2009 regime also limited the data available. Official investigations such as the Legg Report (2010) were restricted in scope, and much pre-2009 empirical material has been destroyed. What counts as 'wrong-doing' or 'corrupt behavior' is also not universally agreed (seen again with the Panama papers). 2 In contrast, data were more publically available under the more formal transparent post-2009 regime, 
but IPSA has identified few formal instances of wrong-doing, making it harder to make direct comparisons and draw robust conclusions.

The paper is structured as follows. First it examines the gaps in the recent work on gender and corruption, focusing on context and levels of accountability before outlining how our approach can fill them. Using these insights, the paper contextualizes the pre-existing UK expenses regime, the scandal itself and its aftermath, before showing how they were gendered. Our new data show that, in the low accountability informal pre-2009 regime, male and female MPs behaved in similar ways - namely female MPs were not less 'corrupt' than male MPs, excepting differences in the employment of family members. Significantly, however, male and female MPs perceived to have 'done wrong' were treated differently by the media and by voters, and our data show they responded differently to sanctioning. We also found evidence that, under the new more formally rule-bound and accountable post-2010 UK expenses regime, women MPs appeared more risk averse than male MPs. The in-depth analysis of the micro-foundations of one case demonstrates that: gender differences in the propensity to act in ways perceived as corrupt are context dependent; levels of accountability play an important role; and female officeholders perceived to be corrupt are treated differently to male office-holders.

\section{Gender and Corruption}

Although there is now considerable scholarship on gender and corruption in economics, development studies and more recently political science, important gaps remain. Existing work finds a robust relationship between gender and corruption (usually defined as either the abuse of public office for private gain 
(The World Bank) or the abuse of entrusted power for private gain

(Transparency International). But there is no unanimity about why the relationship exists, under what circumstances, and the policy prescriptions that flow from it. Recently scholars have also tried to specify more precisely different modes of corruption. Monika Bauhr (2017), focusing on actors' motivation, distinguishes between corruption for need (to receive fair treatment or a service) and corruption for greed (for special advantages). Greed corruption can be legal as well as illegal, is likely to depend on collusion rather than extortion, and can exist in a context of low levels of need corruption and high levels of trust like Sweden. As yet, little work has looked at how these different forms of corruption are gendered.

To date, the relationship between gender and corruption has been investigated in two main ways. First, research using large-scale data sets initially found a link between levels of women's representation (or participation in government) and levels of corruption. Beginning with Dollar, Fisman and Gatti's now classic article (2001), it showed, using general country data, that higher levels of women in parliament were associated with lower levels of corruption. A second influential paper reinforced this contention (Swamy et al 2001). However the explanations proffered were unsophisticated, often relying on notions of women's relative lack of selfishness and higher levels of altruism that meant that they were less likely to engage in corrupt behavior. This thesis had important policy implications for institutions interested in promoting good governance like the World Bank, as it implied that larger numbers of women office-holders would have a positive impact on levels of corruption (for example recruiting more women into police forces) (Swamy et al 2001). 
These findings and their policy prescriptions did not go unchallenged. Sung (2003) contended that the relationship between levels of women's representation and corruption was spurious and that the lower levels of corruption and higher levels of women's representation were both linked to democracy not to each other. Anne-Marie Goetz (2007) argued the relationship between gender and corruption was not a universal one, and that power differences as well as differences in opportunity structures, rather than particular attributes of women as a gender, were a more plausible explanation for any gender-based differences. She also highlighted that much of the research was based only on perceptions of corruption, warning of the dangers of creating a myth based on essentialist assumptions about women's 'higher moral nature' that were then used to inform policy-making.

More recently, large-n studies - many by political scientists - have demonstrated greater analytical specificity, exploring links to particular regime types (as well as focusing explicitly on perceptions of corruption (Barnes and Beaulieu 2014; Watson and Westmoreland 2014)). They found that institutional context matters. Using data from 157 countries over a nine-year period, Esaray and Chirillo (2013), comparing democracies and autocracies, found a gender gap in corrupt behavior and attitudes in democracies with higher female participation in government, but not in autocracies. They claim that this relationship holds only in democracies because there is greater accountability. Esaray and Schwindt-Bayer (2018) have taken this one stage further. Using data from seventy-six democracies between 1990-2010, they show that women in elected office are less likely to engage in corrupt behavior than men when it is risky. They identify electoral accountability, defined as voters' ability to identify 
and then punish corrupt officials at the ballot box, as the causal mechanism. In contexts where corrupt behavior is more likely to be revealed and punished (individual accountability), women are less likely to engage in corrupt behavior; but where accountability is low, women are as likely to engage in it as men. Esaray and Schwindt-Bayer (2018) use four measures of accountability for corruption including press freedom, parliamentary democracy and individual accountability for representatives. They argue that, in a culture of corruption with low of chance of sanction, women politicians are as likely to be corrupt as male politicians, but where corruption is less tolerated with more chance of exposure, women are less likely than men to undertake corrupt activities. Risk aversion therefore plays an important part in their explanation, deterring women from corrupt behavior if the risk of being caught is high. However Esaray and Schwindt-Bayer (2018) too, rely on a presumption of the differential treatment of women found to be corrupt, which they infer from the more general gender and politics scholarship. They (2018) also rely heavily on the gender and corruption scholarship using experimental and individual level data.

This second body of literature - comprising smaller scale studies that look at individual behavior - either uses World Values Survey data (the majority) or experiments (particularly around bribes and lying). Many studies examine individuals' attitudes and levels of honesty and corruption as well as punishment under different circumstances. Some experiments use single country cases like Germany (Schulze and Frank 2003) and Burkina Faso (Armantier and Boly 2011) and one study (Alatas et al 2009) looks at four cases - one developed (Australia) and three developing countries (India, Indonesia and Singapore), and 
a follow-up to the Burkina Faso study contrasts it with Canada (Armantier and Boly 2013).

All find a relationship between gender and (primarily greed) corruption, and some also find that risk of being caught has more influence on individual women than men. Armantier and Boly $(2009,2011)$ found that women were less corrupt than men (namely less willing to accept bribes) if they thought that they would be caught, both in field experiments in Burkina Faso and in the laboratory in Canada. In their laboratory experiments with students in Germany, Schulze and Frank (2003) found that women were equally likely to accept bribes where there was no risk, but more risk averse than men when monitored. Finally in experiments that allowed subjects to choose whether to punish others for corruption, Alatas et al (2009) found that women were less tolerant of corruption in their developed country case, but similarly tolerant in less developed country contexts. Recent experiments that looked at perceptions of corruption also confirm the perception that women are less corrupt than men (Barnes and Beaulieu 2014, 2019). The recent large-n, survey-based and experimental research therefore shows that, while robust, the relationship between gender and corruption is contextually specific. Women are not always 'saints' while men are 'sinners', despite widely held perceptions that women are less corrupt than men. This evidence has also been used to suggest that risk aversion may be more important for women than men. But there is no agreement about the existence of, or explanations for, women's potentially greater risk aversion. Indeed feminist economist Julie Nelson (2017) argues that, because of underlying assumptions about men and women's behavior and 
confirmation bias, small-scale findings about risk are wrongly generalized to all men and women.

Therefore big gaps in our knowledge remain. Some scholars hypothesize that women politicians will be more risk averse than men because they are more likely to be newcomers, less likely to have access to networks that facilitate corruption and fear that they will be punished more severely for any perceived wrong-doing than their male counterparts (Esaray and Schwindt-Bayer 2018). And, despite the widely held assumption that women officeholders are held to different standards than men, as yet there is little robust empirical evidence to support this (Eggers, Vivyan, and Wagner 2018). Most work to date has used only perceptions, experiments or reported behavior to argue that women are punished more severely for corruption than men. To further explore the relationship between male and female politicians, risk aversion and punishment, we use a broad definition of accountability that includes sanctioning, not just by voters, but also by the media, as gender scholars have long emphasized the importance of the differential media treatment of male and female politicians impacting more negatively on female politicians.

Bringing these elements together, the in-depth analysis of one case can show more precisely how this relationship between accountability, risk aversion and corruption is gendered. Scholars in disciplines like anthropology already argue that to understand corruption better, we need to go beyond comparative macro-economic analyses of corruption's causes and effects - often based on quantitative data, experiments and surveys of perceptions - to undertake indepth case-study research (Blundo and Olivier de Sardan 2006). They admit this is difficult, in part because the subject matter makes qualitative data collection 
hard, but also because making a clear distinction between what is and is not corruption is conceptually challenging. Corruption is more often a complex social, rather than individual, activity, occurring in gaps between 'official and professional norms' and actual behavior (Olivier de Sardan 2015). Corruption has two faces: one overtly illegal behavior that is widely condemned; and more frequently, the everyday forms of corruption that are legitimated by social practices, and are tolerated, even encouraged, albeit unofficially (Blundo and Olivier de Sardan 2006). Everyday corruption is therefore 'regulated de facto in accordance with complex rules, and tightly controlled by a series of tacit codes and practical norms. These differ significantly from the public codes and official or legal norms'. (p.3). To understand this form of corruption it is necessary to investigate, not just the breaking of formal official and professional norms, but also of 'practical norms' that inform actual behavior and often make drawing the distinction between corruption and non-corruption so difficult (Olivier de Sardan 2015). This kind of work requires in-depth case-study research.

This formulation fits well with a gendered institutionalist approach that sees institutions as gendered rules, norms and practices that have both formal and informal guises and shape actors' preferences and strategies (Waylen 2014). Institutions are the products of gendered power struggles and understanding the formal 'rules of the game' and their enforcement is crucial. But the informal aspects of institutions - their 'hidden life' - that are often less visible or taken for granted by actors inside and outside institutions - are also central and need to be uncovered (Chappell and Waylen 2013). Although Blundo and Olivier de Sardan (2006) are not identified as institutionalists, Olivier de Sardan (2015) in particular, recognizes that official and professional norms map on to formal rules 
and his concept of practical norms is akin to New Institutionalists' understanding of informal institutions.

This paper adopts a gendered institutionalist approach (informed by insights from the anthropological literature) to undertake an in-depth analysis of gender, corruption and accountability, understanding the pre-2009 UK parliamentary expenses regime as an informal institution, defined by Helmke and Levitsky $(2004,727)$ as 'socially shared rules, usually unwritten that are created, communicated and enforced outside of officially sanctioned channels'. The pre-2009 expenses regime was governed by scant formal rules and numerous informal norms that were generally known and accepted by the participants, but not by the wider public, resulting in low levels of transparency and accountability (defined as sanctioning both by the media and voters). To understand the regime, the subsequent scandal and its aftermath, we must identify the formal and informal rules and norms of the pre-2009 UK parliamentary expenses regime that structured actors' behavior. This enables us to explore any differences in the behavior of male and female MPs and responses to those behaviors, first under the low accountability informal expenses regime, then during the scandal, and finally under the new more transparent and accountable formal expenses regime.

\section{The Context}

\section{The Pre 2009 UK Parliamentary Expenses Regime}

We focus on the expenses regime in force between 2001 and 2008/9, as it remained relatively stable until its replacement in 2010 (after some changes in 2001).3 The informal "gentleman's club" expenses system developed after 1911 
to help MPs carry out their roles in the UK parliament. By 2009 it had become complex to point of being byzantine (vanHeerde-Hudson and Ward 2014). It was based on an underlying assumption of the MP as an 'honorable gentleman' a trustworthy upper class heterosexual man, with a wife and children in his constituency, and a pied-a-terre in London (even if, by the time of the scandal $19 \%$ of MPs were women - numbers having virtually doubled with the election of New Labour in 1997).

By 2009 the regime covered a range of expenses, including staffing constituency and parliamentary offices, travel and communications, as well as MPs' accommodation and subsistence costs, known as the Additional Costs Allowance (ACA). The ACA, introduced in 1971, covered the costs of MPs with constituencies outside London when away from their main home to attend parliament. It was a fixed, but steadily increasing, annual limit (rather than a daily allowance) for expenses. In 1985 it was extended to include mortgage interest payments for a second home and by April 2009 the ACA maximum was $£ 24,222$ p.a. including furniture, repairs and utility bills. The ACA became one of the most controversial parts of expenses regime in the scandal, even though by 2009 staffing costs were the largest budget item.

Several characteristics of the pre-2009 expenses regime make it an informal institution with low levels of accountability and transparency. Rules were loosely specified (described as 'vague, incomplete and inadequate' by Legg (2010)). Few were formally written down or published. Procedures were secret and until late on, few details of MPs expenses were published. MPs therefore were not accountable to the electorate for their expenses claims. Much has been made of the 'culture of entitlement' that existed among MPs (Kelso 2009). MPs' 
expenses were seen as a substitute for pay rises. Few had been awarded for the previous decade or so (even though they were decided by MPs themselves) because large increases were seen as politically unfeasible (Eggers and Fisher 2011). Expenses were treated by MPs, Whips, and parliamentary officials, as a budget to be fully spent and a salary top-up.

Secondly, although from 1987 some basic formal rules were detailed in the Green Books and updated annually, according to Legg $(2010,17)$ these only provided 'general guidelines rather than a detailed code'. Large gaps existed within the official rules. As a result, the day-to-day running of the regime was through informal rules, norms and practices. As one MP said 'what you could claim for depended on who you had last spoken to in the Fees Office as there were no written down rules'.4 The John Lewis list became one of most notorious. This informal list of prices helped the parliamentary officials decide whether ACA claims for furniture and fittings (such as beds, sofas, and TVs) were 'reasonable' based on their cost in John Lewis (a resolutely middle class department store).5 The list was not published or publically/formally codified and it is unclear who knew of its existence until it was confirmed in the run-up to the scandal.6

Thirdly, the regime was administered with a light touch by the Fees Office (FO) within Parliament. It was primarily a system of self-regulation in which the FO advised MPs on what they could, and could not claim, ensuring MPs did not exceed their annual limits amid a 'culture of deference' (CSPL 2009; Kelso 2009). The FO was accused of being too close to MPs and, ex-MP Martin Bell, citing evidence given to the Committee for Standards in Public Life (CSPL), claimed 'creeping collusion between the office and MPs with the office seeing its duty as 
enabling members to claim the maximum, not to police the system (Bell 2009; 38-9). One female MP said she was told by the Fees Office 'don't buy the cheapest, don't buy the most expensive'.7 According to the Legg Report (2010), the FO failed to apply proper limits to disproportionate claims particularly for gardening, and cleaning - although it admitted that the FO often did this for furniture.8 If claims were refused, there was no written-down formal appeals process. 9 There is also little evidence of (third party) sanctions being enforced. Instead there was an assumption of trust and that MPs would act in an honorable fashion as 'gentlemen'. There was often latitude and ambiguity about admissible expenses and the proof of expenditure required. No receipts were needed for food claims for up to $£ 400$ per month and many other items less than $£ 250$ (Worthy 2014). There was little audit and often no evidence provided (Legg 2010, 5). When questioned in 2008, the Director of Parliamentary Resources claimed 'there is checking where there are receipts. Where there are no receipts there is no checking. If it's below $£ 250$ then the assumption is that it's going to be reasonable'.10 Indeed Winnett and Rayner (2009) assert that leaked correspondence showed that a 'degree of co-operation was taking place between the MPs and the authorities, with expenses claims continuing to be met even if there was no immediate evidence or proof of money actually having been spent' $(2009,77)$. The pre-2009 expenses regime was governed by complex social practices, which included tacit codes and practical norms, filling gaps in the formal rules and informing the behavior of the participants.

\section{The Expenses Scandal Unfolds}

Although the expenses scandal finally captured the headlines in May 2009 when the right-wing newspaper The Telegraph published leaked details of individual 
MPs' expenses claims, it had several important antecedents. The first was catalyzed by Parliament's inclusion (with some exemptions) in the Freedom of Information Act (FoI) of 2000, despite some MPs' efforts to have it excluded. To comply with the Act, the House of Commons began publishing crude overall figures for MPs' expenses from October 2004. Journalists and campaigners, who had long been trying to get more information, started making Fol requests for detailed breakdowns of individual MP's claims (vanHeerde-Hudson and Ward 2014). The House of Commons resisted publication using every means possible, but in May 2008 its appeal to the High Court failed (Worthy 2014). It was during this process that some mechanisms of the expenses regime, like the absence of receipts and the 'John Lewis List', first came to light (Winnett and Rayner 2009). At the same time, evidence of wrong-doing by individual MPs entered the public domain. The case of a Conservative MP who had paid his son a large salary while a full-time student highlighted the potential for abusing the employment of family members (Kelso 2009, Eggers and Fisher 2011). Although the House of Commons had finally agreed to publish expenses claims in June 2009 and committed itself to a far-reaching review by the Committee on Standards in Public Life (CSPL 2009), its response was so slow, that it was The Telegraph's publication of leaked data that catalyzed the fully-blown crisis.

The subsequent press scrutiny was intense. The huge media coverage of the scandal was sustained, predominantly condemnatory and the public reaction to the revelations very negative (Kelso 2009). But perhaps surprisingly, voters subsequently 'punished' MPs less severely at the 2010 General Election than might have been expected from the negative media coverage. Pattie and Johnston (2012) claim that, on average, 'punishment' amounted to a $1.5 \%$ 
decline in vote share, a figure reinforced by Eggers and Fisher's (2011) data, but neither study disaggregated by MP's sex.

The scandal did have several institutional repercussions. In response to the widespread media and public outcry, retired civil servant Sir Thomas Legg was appointed to independently review all MPs' ACA expense claims made between 2004-9, publishing his report in February 2010. Overall, Legg investigated 751 MPs (141 (19\%) were female and 610 male). Legg found 52\% of MPs investigated to have made invalid claims either because they were in breach of the Green Book rules or because they 'breached the essential requirement of propriety', either through disproportionate claims, or in a small number of cases, because transactions were 'conflicted' (Legg 2010).11387 MPs were ordered to make repayments ranging from $£ 104$ to $£ 45,500$ (after appeal). Of these, $65 \%$ had to pay less than $£ 1000$ and the average repayment after appeal was $£ 1500$ (Pattie and Johnston 2012; vanHeerde 2014; Eggers and Fisher 2011).

Very few MPs had engaged in outright illegal behavior - the vast majority of claims were within the law and, most were within the formal rules - even if they had been widely pilloried in the media or later deemed to be dishonourable or inappropriate (vanHeerde Hudson and Ward 2014). It is therefore hard to establish exactly where the division between corrupt and non-corrupt behavior lies in the expenses scandal. The Telegraph gave huge attention to what it considered 'wrongful' claims for tiny items like individual chocolate bars that were clearly within the formal and informal rules and for minimal amounts of money. Thomas Legg, too, had narrow terms of reference for his investigation. He looked only at abuse of the ACA rules and standards at the time, excluding 
'flipping' (changing the designation of a second home between London and the constituency), as this would question the whole ACA system and so was beyond his remit (Legg 2010,14). Legg also did not consider any MP under investigation by the Parliamentary Standards Commissioner or Police, or any issues concerning tax. So some MPs who were widely vilified in the media, later convicted for fraud or forced to resign, for example for tax avoidance, were largely exonerated by Legg because they did not transgress in his narrow framework. As a result, the Legg report's utility as a guide to the extent of MPs' 'wrong-doing' has limitations and has to be supplemented with additional data.

\section{The new IPSA Expenses Regime Post 2010}

The second institutional response to the scandal was the hurried, and somewhat confused, institutional design process informed by the CPSL Report (2009). It established a new formal more transparent expenses regime, overseen by the newly created Independent Parliamentary Standards Authority (IPSA) in 2010. This was more restrictive and inflexible (e.g. in its accommodation of family life). Second home allowances were limited to the rental of a one bedroom flat in London, with mortgages or furnishings excluded. Dependents now had to be formally registered before any allowances could be paid. But, despite recommendations to the contrary in the CSPL report (2009), after an outcry MPs could still employ one family member (or 'connected party'). Under the new IPSA regime, all claims were published online but very few were deemed ineligible or 'not under scheme' (but not necessarily wrongful), making it hard to generalize about patterns of 'wrong-doing'.

The new restrictive regime did not stop media claims that MPs were still manipulating the rules for gain. In addition to the continued negative coverage 
of the employment of connected parties (Sunday Times 3 April 2016), there were repeated reports of MPs renting out their own properties to claim the second home allowance on another rented property. In 2012 twenty-seven MPs were allegedly renting out London properties (four of them to other MPs) (The Sun and Daily Mail 19 Oct 2012). Other reports suggested that MPs claimed dependents' allowance to supplement their salaries. Under the headline 'MPs use children to claim more expenses', The Telegraph (16 October 2015) asserted that some of 148 MPs registered as having dependents 'have made more than $£ 10,000$ on the scheme'.12

\section{Gendering the Expenses Scandal}

We can now consider how the scandal was gendered by examining how far male and female MPs behaved differently, exhibiting different claim patterns, firstly under the informal low accountability expenses regimes before the scandal and subsequently under the more formal, transparent accountable expenses regime introduced after the scandal; as well as examining whether male and female MPs were treated differently by voters and the media.

\section{MPs' Overall Expenses Claims Pre2009}

From 2001-2009, we find no significant differences in male and female MPs claims under the informal expenses regime (see table 1, appendix). Although women MPs were more likely to appear in lowest claim category than men (31.6\% v 25.6\%); they had a similar level of claims in middle category (50.9 versus $50.8 \%$ ) but were less likely to be in top category (17.5\% versus $23.7 \%$ ) between 2001-4 (Besley and Larcinese 2011). 
Despite similarities in total claims, we found evidence of gender differences in MPs' claims in two categories - accommodation and staffing - in 2007/8. Although differences in overall accommodation costs between male and female MPs are not statistically significant and do not affect our argument, they conceal important differences in the living arrangements of female MPs with dependent children relative to all other MPs. These female MPs were much more likely to be based primarily in London with a second home in their constituency. The relative flexibility and 'gender friendliness' of the informal expenses regime facilitated this difference in living arrangements in comparison to the post 2010 regime.

Table 1: 2007/2008 MPs' Accommodation Claims by Sex (Data compiled from Telegraph Database13)

\begin{tabular}{|l|c|c|c|}
\hline Claim Total & Female & Male & Total \\
$£ 70-£ 7840$ & $36.4 \%(44)$ & $32.6 \%(171)$ & $33.3 \%(215)$ \\
$£ 14171$ and above & $28.1 \%(34)$ & $34.5 \%(181)$ & $33.3 \%(215)$ \\
Total & $100 \%$ & $100 \%$ & $100 \%$ \\
\hline $\mathrm{N}$ & 121 & 525 & 646 \\
\hline
\end{tabular}

$\mathrm{Chi}^{2}=1.82 \quad \mathrm{P}$ value $=0.40$

There are also important differences in staffing patterns - rather than overall staffing costs - relevant to our argument. Our analysis of The Telegraph database shows that between 2005-9 nearly 31\% of MPs employed a family member (also 
known as 'connected parties'). For critics, this provided incontrovertible evidence of MPs exploiting the expenses regime to increase their overall remuneration, whereas for others it was simply a way for hard-pressed MPs to keep families together while doing a difficult and stressful job (CSPL 2009). The CSPL Report $(2009,57)$ does note, however, that family members were on average paid slightly more and received higher bonuses.

Our analysis of The Telegraph database reveals marked gender differences in the employment of family members. While $33 \%$ of male MPs employed a family member (or 'connected party'), only 23\% of women MPs did so, which is statistically significant (Chi2 p-value $=0.04$, and F-statistic $=4.27$ ). This effect remains when you analyze MPs by cohort/length of service as well as gender (see tables two and three, appendix). In 2009, 71.5\% of male MPs' employees were their female spouses - indeed 83\% of male MPs employing a connected party were employing their wife (see table four, appendix). In contrast, only $50 \%$ of female MPs employing a connected party employed a spouse (54\% including partners). Furthermore, of the male spouses employed, around $50 \%$ were described as parliamentary or senior parliamentary assistants likely to be based at Westminster, followed by office managers (35\%) or other relatively senior-sounding jobs (senior case worker, executive secretary). For male MPs' wives, the biggest employment category was secretarial (41.3\%) or office manager (29\%), but only $10 \%$ were some form of parliamentary assistant likely to be based in Westminster. Female MPs were more likely to employ a child. Children comprised 29\% of female MPs' connected parties but only $6 \%$ of male MPs'. The Parents in Parliament data provide part of the explanation. Campbell and Childs (2014) found that in 2012/3 the children of female MPs (if 
they had them) were older than male MPs' children (on average sixteen versus twelve years old when the MP entered parliament). Therefore, while total overall claims were similar, the spending patterns of male and female MPs were different. These differences result primarily from the differing domestic arrangements of many male and female MPs.

Table Two: Actions Required of MPs by the Legg Report14 


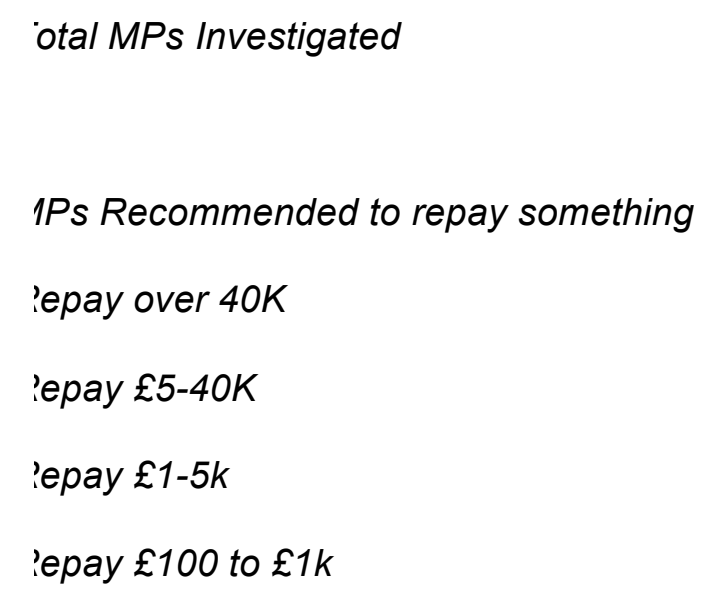

19.4

$387(51.5 \%) \quad 312(51.1 \%) \quad 75(53.1 \%) \quad 80.6 \quad 19.4$

$3(0.8 \%) \quad 2(0.6 \%) \quad 1(1.3 \%) \quad 66.6 \quad 33.3$

$56(14.4 \%) \quad 46(14.7 \%) \quad 10(13.3 \%) \quad 82.1 \quad 17.9$

\section{MPs' Patterns of 'Wrong-doing'}

The starting point for our analysis of pre 2009 patterns of 'wrong-doing' is the Legg report. As the first analysis to disaggregate Legg's findings by sex, we find 
no disproportionate differences in numbers of male and female MPs in any category (see table two). Overall $53.2 \%$ of female MPs and $51.1 \%$ of male MPs investigated were asked to repay some expenses. As table two shows, all outcomes are proportionate to the overall make-up of the Commons at that time. A regression analysis, controlling for party and region, also shows no significant differences between male and female MPs (see tables five to eight, appendix). The only notable difference is that women were over-represented in the 'yet to repay' category because the Conservative party leader had ordered his, predominantly male, MPs to repay immediately. The over-representation of female MPs among $£ 40,000+$ category is based on a very small $\mathrm{N}$ (one female MP).

Due to the narrow scope of Legg's investigation, we adopted a broader remit, combining data from the Legg Report, The Telegraph (and other media sources), as well as the parliamentary database, to gain a more comprehensive understanding of any gendered patterns of wrong-doing. We divided 'wrongdoing' into three categories, reflecting perceived seriousness and risk. The first two - excessive and overpaid claims and manipulation of the rules - comprise various forms of 'everyday corruption' and the third is overtly illegal activity. Excessive or Overpaid Claims

We found no significant gender differences in any subdivision within the excessive, unnecessary or overpaid claims that engendered huge public notoriety (and included the notorious examples of the duck house and moat cleaning as well as a plasma television, trouser press, Christmas decorations and hanging baskets). There were no gender differences in claims for furnishings and other spending on items for second homes that either exceeded the John Lewis 
unofficial limit, or were not permitted, such as antiques and garden furniture. Again there were no differences in the second sub-category of cleaning and gardening costs retrospectively deemed excessive by Legg in the absence of guidelines.15 And there were also no gender differences in the final and largest sub-category of the overpayment of bills (primarily mortgage repayments and council tax bills, but also utilities and service charges) (see table three).

\section{Manipulation of the rules}

The second category to attract widespread media vilification were expenses claims where the rules, although not necessarily broken, appeared to have been deliberately manipulated for private gain. Of the three types of rule manipulation, only two were investigated by Legg: carrying out extensive repairs and redecoration just prior to the sale of a property or the MP standing down; and remortgaging for purposes that did not fall within ACA. The instances of both redecoration and remortgaging were very low. Within these sub-categories there are no sex differences (see table three). Legg also highlighted a small number of conflicted transactions, such as renting from a close family member and miscellaneous ones (such as overpayment for food, room service hotel charges, removals costs). Again there are no significant differences between male and female MPs. The third type - the re-designation of second homes ('flipping') as a main residence and vice versa, often for significant financial gain through the ACA allowances and tax avoidance if the property was sold - fell outside Legg, but deserves particular attention here because it drew so much media opprobrium. 
Table three: MPs repaying in different categories (Data and table derived from the Legg Report)16

\begin{tabular}{lll}
\hline & $\begin{array}{l}\text { \% Female MPs asked to } \\
\text { repay (N) }\end{array}$ & \multicolumn{1}{l}{ repay (N) } \\
\hline Excessive Claims or Overpayment & & $19.20 \%(60)$ \\
Furnishing & $22.70 \%(17)$ & $20.50 \%(64)$ \\
Cleaning / Gardening & $20 \%(15)$ & $70.50 \%(220)$ \\
Bills & $68 \%(51)$ & $1 \%(3)$ \\
\hline Manipulation of the Rules & & $1.90 \%(6)$ \\
Redecoration & $4 \%(3)$ & $1.60 \%(5)$ \\
Re-mortgaging & $0 \%(0)$ & $7.70 \%(24)$ \\
Conflicted Transactions & $2.70 \%(2)$ & \\
\hline Miscellaneous & $5.30 \%(4)$ & \\
\hline
\end{tabular}

Despite the media claims that flipping was widespread (e.g The Mail, 17 March 2010, claimed that 232 MPs had flipped over the previous five years), it is hard to determine from Parliament's own figures how far they show deliberate manipulation for gain. The majority of re-designations were in the same location e.g. within the constituency, rather than moving from London to the constituency or vice versa. In one year, 2008/9, fifty-three MPs, of which ten (19\%) were women, changed the designation of their second home (see The Guardian 10 Dec 2009). But only fourteen MPs (26\%) flipped from their constituency to London or vice versa, the majority either maintained their second home in the same 
location or started using hotels. Of these, two were women - i.e. $14 \%$ of the total. The data for the period 2004-9 again show no disproportionate gender effect (see table nine, appendix). 20\% of flipping MPs were female, in line with the gender composition of parliament at the time. During this period, five male MPs and two female MPs changed the designation of their second home from their constituency to London or vice versa more than once. Therefore 'flipping' too, shows no substantive evidence of significant sex differences.

\section{Criminal activity}

The third category of expenses abuse was clearly illegal and potentially high-risk behavior - such as falsifying receipts or claiming for mortgages that no longer existed. Of the six MPs convicted of outright criminal and fraudulent activity, five were men (Devine, Morley, Chaytor, MacShane and Illsley). One female MP (Moran) was found guilty but was deemed unfit to stand trial (for flipping to her partner's house - not in her constituency or London - in order to claim for dry-rot treatment).

Overall therefore, we found little evidence that female MPs behaved significantly differently to male MPs under the informal and unaccountable pre2009 expenses regime, either in their overall claim patterns (with some exceptions like the employment of family members) or 'wrong-doing', whether it was some form of 'everyday' greed corruption, such as the seemingly low-risk excessive claims, the potentially more risky outright rule manipulation, or highrisk criminal activity. However, although our data show that female MPs were not less guilty of 'wrong-doing' or less risk averse than their male counterparts, we also need to explore whether they were treated differently by the media and by voters, and responded differently to the scandal. 


\section{Responses to the Scandal}

\section{Media and Voters}

From May 82009 when the scandal broke until the 2010 general election, there was substantial gender bias in coverage in all types of newspapers (Larcinese and Sircar 2014, 2017). Analysing seven tabloid and broadsheet newspapers identified with different points on the political spectrum, Larcinese and Sircar unexpectedly found that, alongside front bench and more senior MPs, female MPs were mentioned significantly more frequently than expected, an effect that strengthened as more controls were added.17 Female MPs, too, felt that they received more unwarranted negative coverage. One female MP stated with regard to her expenses claims that 'the press spun this as a negative story for me despite the fact that I was not required to pay any money back'. It didn't matter what good work I was doing - this would usually come up in a newspaper article when I was googled. And Jacqui Smith was held up as the "poster girl" of the expenses scandal - yet those who went to prison were all men.' (quoted in O’Neill and Savigny 2014, 20).

Larcinese and Sircar (2017) also found that female MPs were punished more than male MPs when they looked at who was voted out (rather than losing vote share) after controlling for factors such as marginality and length of service. They (2017) found that the level of media coverage post-scandal was a significant factor in losing votes. But although the electoral effect was more severe for female MPs than for male MPs, the gender differences were less marked than in the press coverage, implying gendered sanctioning by the media was greater than by the electorate.

MPs' Responses to the Scandal 
Male and female MPs differed in their responses to the scandal, both in their decisions about their political careers and their public responses. A post war record of 149 MPs (twenty-eight of them women) stood down before the 2010 general election (comprising 100 Labour MPs, including twenty-two women, and thirty-five Conservative MPs, including five women). The large number, roughly double the usual figure and nearly a quarter of the total number of sitting MPs, was attributed to the expenses scandal and the subsequent threat to MPs' redundancy pay and pensions (The Telegraph 28 December 2009). Our data both quantitative and qualitative - show that female MPs implicated in the expenses scandal were more likely to stand down than their male counterparts, using a measure of implication that includes both attention from the media and Legg (see table six ten, appendix). Only $30 \%$ of male MPs (thirteen) and two (17\%) female MPs who announced that they would be standing down before the scandal broke in May 2009 were later implicated in it. This situation was reversed after May 2009 when $58.8 \%$ of all female MPs (ten) but only $45.5 \%$ of all male MPs (thirty) who announced they were standing down during and after the Telegraph revelations were implicated in the scandal (see table ten, appendix). The gender difference remains if we consider whether MPs were nearing retirement, and marginality did not change it either (see tables eleven and twelve, appendix). Larcinese and Sircar's (2017) data also reinforce our findings. Comparing the numbers of MPs who announced they were standing down pre and post-scandal Larcinese and Sircar (2017) found that, although gender was not a factor before, it was afterwards and that there was a significant interaction effect with media coverage.18 
Allington and Peele (2011) also examined MPs' website pronouncements about expenses - both their own conduct and expenses in general. Among the $10 \%$ of MPs without a website, and the $24 \%$ of MPs who did not comment about the scandal on their website, the number of women matched their presence in the House of Commons. However, proportionately more women than men responded to the scandal by providing links to their own claims or commenting on the scandal on their websites (Allington and Peele 2011). Overall therefore, female MPs were more likely to face media sanctioning. They were more likely than male MPs to stand down and more likely to lose votes if facing media sanctioning. Therefore the disproportionate media coverage contributed to a 'double whammy' for female MPs - both on their decision to leave parliament and the likelihood of losing their seat - in the wake of the scandal. MPs' responses to the post 2010 expenses regime The final element to consider is MPs' responses to the new, more formal, transparent and accountable expenses regime overseen by the newly-created independent Parliamentary Standards Authority (IPSA). Several factors mean that comparisons with pre 2009 are not straightforward. First, because of the huge turnover, nearly 33\% of MPs were new (of these nearly a third were women). The total number of women increased only slightly from 128 to 143 MPs (22\%), predominantly due to the 36 new Conservative female MPs, rising from seventeen to forty-nine (34.3\% of all women MPs). The number of Labour women MPs declined from ninety-eight ( $80 \%$ of all women MPs) to eighty-one (56.6\%) as the thirty-two new Labour women did not replace the forty-nine who had lost or stood down. As a result, half of women MPs, but only about 30\% of male MPs, were new. 
We can highlight several outcomes. First, the post-scandal employment of 'connected parties' changed. The proportion of MPs employing a connected party fell to $23.6 \%$ (from $31 \%$ ) by $2012 / 3$. But this figure conceals some statistically significant sex differences $\left(\mathrm{Chi}^{2} \mathrm{p}\right.$ value $=0.00, \mathrm{~F}$-statistic 11.64$)$. The proportion of male MPs employing a connected party only fell by about a quarter to $26.6 \%$ (from $32.8 \%$ ), whereas the proportion of female MPs employing a connected party almost halved to $12.9 \%$ (from $23.1 \%$ ) (see table thirteen, appendix). These differences remain when disaggregating by length of time in parliament (see table fourteen, appendix). Second, there were only 400 'not under scheme' (ineligible) claims between 2010-2014, a tiny proportion of the approximately 800,000 itemised claims. Only $17 \%$ were made by women MPs, compared to the $22 \%$ of MPs who were female (the $0.06 \mathrm{p}$-value of this difference is almost statistically significant, see table fifteen, appendix). But, sorting claims by individual, we see that the top twelve repeat offenders were all male (table sixteen, appendix). Some of these MPs had multiple 'not under scheme' claims. The contrast with female MPs' repeated 'not under scheme' claims is stark (see table sixteen, appendix). The largest number of male 'not under scheme' claims was twenty-four, compared to a maximum of five for female MPs. Some male MPs appeared undeterred by the rejection of multiple claims, often simply blaming their office staff.

In addition, the continuing adverse publicity led some, including our female MP interviewees, to assert that MPs now under-claimed to maintain privacy for themselves and their families, preventing further media intrusion, and that female MPs do this disproportionately as the media is particularly critical of mothers of young children.19 One female Labour MP reported that 
'They (the media) question why you have a flat in London with more than one bedroom, or why your young child has to travel on the train with you' (quoted in O'Neill and Savigny 2014, 20). Our data also show that female MPs altered their overall claim patterns, including their accommodation claims, more than male MPs.20

\section{Conclusions}

The simple contention that women are less corrupt than men is no longer tenable. Our in-depth analysis of one instance of corruption - the pre-2009 UK parliamentary expenses regime, the 2009 scandal and its aftermath - illuminates several key aspects of the relationship between gender and corruption. We demonstrate how levels of accountability affect male and female office holders' propensity for corruption. First, in a context of low accountability i.e. where the media and voters were unable to identify or punish/sanction abuses, our data show that female MPs behaved similarly to male MPs and not less 'corruptly'. Immediately prior to the scandal, women MPs' overall expenses claims were similar to male MPs', as were their patterns of 'wrong-doing', whether 'everyday' greed corruption such as excess claims and manipulation of the rules, or the potentially more risky outright illegal activity. We can explain the main differences in male and female MPs' expenses claims - the employment of connected parties and location of second homes - largely by the social differences in men's and women's lives, around caring responsibilities and the differing roles in public and private spheres that impact on their employment and parenting, rather than their differing propensity for corruption in that context. 
Second, our data show significant gender differences in behavior during and after the scandal. These differences could be seen to support the general thesis that women office-holders are more risk averse than men in contexts of higher accountability like the new formal, expenses regime, where greater transparency facilitates the identification of and punishment of 'wrong-doing'. Female MPs appeared to change their behavior - both in response to the scandal and the new formal transparent and accountable regime - more than male MPs. They were more likely to stand-down after negative press coverage. Furthermore, under the new formal IPSA regime, women MPs reduced their levels of employment of connected parties more, and were less likely to be serial offenders with 'not under scheme' claims than male MPs.

Third, we need however to add to the analysis the significant gender differences in the ways that male and female MPs seen as corrupt were treated. Female MPs were punished/sanctioned more than male MPs, particularly by the media, but also by the electorate for perceived wrong-doing, (echoing the more general treatment of female politicians). So we contend that behavior that might be attributed to women's greater risk aversion could be an entirely rational response by women office-holders to higher levels of punishment/sanction by the media and electorate. This general proposition needs further investigation as part of on-going research on gender and risk aversion.

Finally, by directly comparing a context of low and high accountability, the in-depth analysis of one case contributes new insights to wider debates on gender, corruption and accountability. Using an approach that understood the low accountability, pre 2009, expenses regime as an informal institution enabled us to explore the complex norms, informal rules and practices of predominantly 
'everyday' corruption as a regulated social, not just individual, activity. We could only have discerned the context-dependent nature of the gender differences in corruption by using a single case - allowing us to uncover the micro-foundations and precise mechanisms of similarities and differences in the behavior of male and female office-holders - giving us insights into larger patterns and new research agendas.

\section{NOTES}

1. Harriet Harman, Leader of the House, and Gordon Brown, the Prime Minister, called it a 'gentleman's club' during the scandal.

2. The Panama papers, $11.5 \mathrm{~m}$ files leaked in 2016 from a Panama-based offshore law firm, sparked debates about tax evasion and avoidance and the morality versus legality of acts construed as 'wrong-doing'.

3. Several amendments in 2008/9 responded to increasing disquiet, but few were fully implemented before the regime's replacement.

4. Interview, July 11, 2016.

5. E.g. it included $£ 1000$ for a bed, $£ 10,000$ for a new kitchen and $£ 750$ for a television, http://news.bbc.co.uk/1/hi/uk_politics/7295150.stm).

6. Fees Office Official, Interview March 9, 2016. Three (female) MPs interviewed said they had had no knowledge of it (July 2016).

7. Interview, July 19, 2016.

8. Armitage (2014) too found evidence that the FO rejected claims for being too luxurious.

9. Interview, Fees Office Official, March 9, 2016. 
10. Evidence from Andrew Walker, Director of Parliamentary Resources, to Information Tribunal hearing an FoI request, February 7, 2008.

11. MPs who could not produce the requisite evidence were ordered to repay (Legg p.6).

12. One male MP was charged with falsely claiming for a dependent child in 2016.

13. For Telegraph database see http://parliament.telegraph.co.uk. It contains details of all MPs' expenses between 2004-08.

14. Data generated by Faith Armitage.

15. Legg deemed more than $£ 2000$ p.a for cleaning and $£ 1000$ p.a for gardening excessive. $93 \%$ of the 574 MPs claiming cleaning, claimed less than $£ 2000$ p.a. 16. The total number of MPs is higher than in table three because some MPs, repaying in several categories, appear more than once.

17. They captured mentions of each MP (minus party leaders and the speaker) using the natural log of mentions across the time period as the dependent variable in an Ordinary Least Squares regression analysis.

18. For Larcinese and Sircar 'the most noticeable difference between pre and post-scandal patterns can be found in gender: female MP's had a higher likelihood of standing down when facing news media pressure on the scandal. The placebo (here, female MPs announcing they were standing down before the scandal broke) regression...indicates that no such pattern can be found for prescandal retirement'. This is compatible with Jennifer vanHeerde-Hudson's (2014) absence of a strong gender effect because she did not differentiate between pre and post-scandal decisions to stand down or between those receiving media attention. 
19. All female MPs interviewed stressed this.

20. E.g. in 2012 female MPs with dependent children were more likely to have their second home in London, a change from pre2009.

\section{REFERENCES}

Alatas, Vivi. Lisa Cameron., Ananish Chaudhuri., Nisvan Erkal. Lata Gangadharan. 2009. Gender, culture and corruption: insights from an experimental analysis. Southern Economic Journal. 75(3):663-80.

All Party Parliamentary Group for Women in Parliament. 2014. Improving Parliament: Creating a Better and More Representative House. Inquiry Report. Allington, Nigel. and Gillian Peele. 2010. Moats, duck houses and bath plugs: Members of Parliament, the expenses scandal and the use of web sites. Parliamentary Affairs. 63(3):385-406.

Armantier, Olivier. and Amadou Boly. 2011. A controlled field experiment on corruption. European Economic Review. 55(8):1072-82.

Armantier, Olivier. and Amadou Boly. 2013. Comparing corruption in the laboratory and in the field in Burkina Faso and in Canada. The Economic Journal. 123(12):1168-87.

Armitage, Faith. 2014. Paying for our politicians: MPs expenses and institutional rules. Paper presented at the PSA Annual Conference, Manchester.

Barnes, Tiffany. and Emily Beaulieu. 2014. Gender stereotypes and corruption: how candidates affect perception of electoral fraud. Politics \& Gender. 10(3):365391. 
Bauhr, Monika. 2017. Need or greed? Conditions for collective action against corruption. Governance. 30(4):561-581.

Bell, Martin. 2009. A Very British Scandal: The Expenses Scandal and how to save our democracy. London: Allen and Unwin.

Besley, Tim. and Valentino Larcinese. 2011. Working or shirking? Expenses and attendance in the UK parliament. Public Choice. 147:291-317.

Bjarnegard, Elin. 2013. Gender, Informal Institutions and Political Recruitment. Basingstoke: Palgrave.

Blundo, Giorgio. and Jean-Pierre Olivier de Sardan. 2006. Everyday Corruption and the State: Citizens and Public Officials in Africa. London: Zed Press.

Campbell, Rosie. and Sarah Childs. 2014. Parents in parliament: where's Mum? The Political Quarterly. 85(4):487-92.

Chappell, Louise. and Georgina Waylen. 2013. Gender and the hidden life of institutions. Public Administration, 91(3):599-615.

CSPL (Committee for Standards in Public Life). 2009. MPs' expenses and Allowances: supporting Parliament, Safeguarding the Taxpayer. Cm 7724, London: HMSO.

Dollar, David, Raymond Fisman, and Roberta Gatti. 2001. Are women really the 'fairer' sex? Corruption and women in Government. Journal of Economic Behavior \& Organization. 46(4):423-429.

Eggers, Andrew, and Alexander Fisher. 2011. Electoral accountability and the UK parliamentary expenses scandal: did voters punish corrupt MPs? mimeo, LSE. Eggers, Andrew, Nick Vivyan, and Markus Wagner. 2018. “Corruption, accountability and gender: do female politicians face higher standards in public life. Journal of Politics. 80(1):321-326. 
Esaray, Justin and Gina Chirillo. 2013. "Fairer Sex" or purity myth? Corruption, gender and institutional context. Politics \& Gender. 9(4):361-389.

Esaray, Justin. and Leslie Schwindt-Bayer. 2018. “Women's representation, accountability and corruption in democracies. British Journal of Political Science. 48(3):659-690.

Gay, Oonagh. 2014. The new regime: the role of IPSA in Jennifer van HeerdeHudson. ed. The Political Costs of the 2009 British MPs Expenses Scandal. Basingstoke: Palgrave.

Goetz, Anne-Marie. 2007. Political cleaners: women as the new anti-corruption force?. Development and Change. 38(1):87-101.

Graffin, Scott, Jonathan Bundy, Joseph Porac., James Wade. and Dennis Quinn. 2013. Falls from grace and the hazards of high status: the 2009 British MPs expenses scandal and its impact on parliamentary elites. Administrative Science Quarterly.58(3):313-345.

Helmke, Gretchen. and Steven Levitsky. 2004. Informal institutions and comparative politics: a research agenda. Perspectives on Politics. 2(4):725-40. Kelso, Alexandra. 2009. Parliament on its knees: MPs expenses and the crisis of transparency at Westminster. The Political Quarterly. 80(3):329-338.

Larcinese, Valentino. and Indraneel Sircar. 2014. Singing from the Same Broad Sheet? Examining Newspaper Coverage Bias during the 2009 MPs Expenses Scandal." in Jennifer van Heerde-Hudson. (ed). The Political Costs of the 2009 British MPs Expenses Scandal. Basingstoke: Palgrave.

Larcinese, Valentino. and Indraneel Sircar. 2017. Crime and punishment the British way: accountability channels following the MPs expenses scandal. European Journal of Political Economy, 47:75-99. 
Legg, Thomas. 2010. Review of past ACA payments. House of Commons Members Estimates Committee. First Report of Session 2009-10.

Lowndes, Vivien. and Martin Roberts. 2013. Why Institutions Matter: The new Institutionalism in Political Science. Basingstoke: Palgrave.

Nelson, Julie. 2017. Gender and Risk-Taking: Economics, Evidence and Why the Answer Matters. London: Routledge.

Olivier de Sardan, Jean-Pierre. 2015. Practical norms: informal regulations within public bureaucracies (within Africa and beyond). In Tom. De Herdt and Jean-Pierre Olivier de Sardan. eds. Real Governance and Practical Norms in SubSaharan Africa. London: Routledge.

O’Neill, Deirdre and Heather Savigny. 2014. Female politicians in the British press: the exception to the 'masculine' norm?. Journal of Journalism Education. $3(1): 6-22$.

Pattie, Charles. and Ron Johnston. 2012. The electoral impact of the 2009 MPs expenses scandal. Political Studies. 60(4):730-50.

Schulze, Gunther. and Bjorn Frank. 2003. Deterrence versus intrinsic motivation: experimental evidence on the determinants of corruptibility. Economics of Governance. 4(2):143-60.

Stenstota, Helena., Lena Wangnerud. and Richard Svensson. 2014. Gender and corruption: the mediating power of institutional logics. Governance. 28(4):47596.

Sung, Hung-En. 2003. Fairer sex or fairer system? Gender and corruption revisited. Social Forces. 8(2):703-23.

Swamy, Aanand, Stephen Knack, Young, Lee. and Omar Azfar. 2001. Gender and corruption." Journal of Development Economics. 64(1):25-55. 
vanHeerde-Hudson, Jennifer. 2014. Should I stay or should I go? The impact of the expenses scandal on MPs decisions to stand down." in Jennifer vanHeerdeHudson. ed. The Political Costs of the 2009 British MPs Expenses Scandal. Basingstoke: Palgrave. vanHeerde-Hudson, Jennifer. ed. 2014. The Political Costs of the 2009 British MPs Expenses Scandal. Basingstoke: Palgrave.

Vivyan, Nick. Marcus Wagner. and Jessica Tarlov. 2012. Representative misconduct, voter perceptions and accountability: evidence from the 2009 House of Commons expenses scandal. Electoral Studies. 31(4):750-763.

Wangnerud, Lena. (2012). Why women are less corrupt that men. in Soren Holmberg and Bo Rothstein. eds. Good Governance: The Relevance of Political Science. London: Edward Elgar.

Wangnerud, Lena. (2015). Gender and Corruption. in Paul Heywood ed Routledge Handbook of Political Corruption. London: Routledge.

Watson, David. and Amy Moreland. 2014. Perceptions of corruption and the dynamics of women's representation. Politics \& Gender. 10(3):392-412. Waylen, Georgina. 2014. Informal institutions, institutional change and gender equality. Political Research Quarterly. 67(1):212-23.

Winnett, Robert. and Gordon Rayner. 2009. No Expenses Spared. London: Bantam Press.

Worthy, Ben. 2014. Freedom of Information and the MPs' expenses crisis. in Jennifer van Heerde-Hudson. ed. The Political Costs of the 2009 British MPs Expenses Scandal. Basingstoke: Palgrave. 
